Милорад Миљаковић

Универзитет у Новом Саду

Филозофски факултет

Катедра за славистику

milorad.miljakovic@ff.uns.ac.rs
УДК 811.16'366'373

https://doi.org/10.18485/slavistika.2020.24.2.15

оригинални научни рад

примљено 23.05.2020.

прихваћено за штампу 18.09.2020.

\title{
ТВОРБЕНИ НАЧИНИ ЗА ИМЕНОВАЬЕ ПРИПАДНИКА МУЗИЧКИХ ПОТКУЛТУРА У СРПСКОМ, РУСКОМ И ПОљСКОМ ЈЕЗИКУ
}

У раду је извршена типолошка анализа творбених начина за именовање припадника различитих музичких поткултура (нпр. срп. металащ; pус. металлист; пољ. metalowiec/metal) на материјалу српског, руског и пољског језика. Основни корпус је ексцерпиран из речника жаргона и једнојезичних речника, део корпуса је прикупљен уз помоћ интернетске претраге и анкете, коју су попунили изворни говорници српског, руског и пољског језика. Поред именица које означавају припаднике одређене поткулутуре у раду се анализирају и могућност и начини творбе одговарајућих фемининатива (нпр. срп. металка; рус. металлистка; пољ. metalówka/metal/metalówa), пејоратива (нпр. срп. реперчић/penерчина; рус. рэпитос; пољ. raperzyna), или пак аугментатива, који у одређеним контекстима немају пејоративни карактер, већ представљају аугментативе са сублимираном позитивном оценом (нпр. срп. Дадо, реперчино, уметниче, обележио си ту зиму...).

Кључне речи: музички жаргон, творба речи, суфиксација, позајмљенице, српски језик, руски језик, пољски језик.

This paper contributes a typological analysis of derivative models for referring to the members of different musical subcultures (e.g. Ser: металаu; Rus: металлист; Pol: matalowiec/metal), based on the material from Serbian, Russian and Polish. The main corpus is taken from the slang dictionaries and monolingual dictionaries, while another part of the corpus is collected through the online survey, which was completed by the native speakers of Serbian, Russian and Polish. Alongside the main topic, this paper depicts the derivation process of three further derivatives: femininative nouns (e.g. Ser: металка; Rus: металлистка; Pol: metalówka/metal/metalówa), pejorative nouns (e.g. Ser: реперчић/реперчина; Rus: рэпитос; Pol: raperzyna), or augmentative nouns, which in certain contexts do not carry a pejorative meaning, but they represent augmentative nouns with positive connotations (e.g. Ser: Дадо, реперчино, уметниче, обележио си ту зиму...).

Keywords: music slang, derivation, suffixation, loanwords, Serbian, Russian, Polish.

\section{1. ЦИљ, МЕТОД И КОРПУС РАДА}

У раду ће бити извршена типолошка анализа творбених начина за именовање припадника различитих поткулутра на материјалу српског, руског и пољског жаргона. Почетна идеја истраживања подразумевала је ексцерпирање основног дела корпуса из доступних речника жаргона. Ипак, услед недовољног броја прикупљених примера у корпус улазе и једнојезични речници стандардног језика, интернетска претрага и примери прикупупљени анкетирањем испитаника. Рад се бави и анализом творбених начина за именовање припадница, тј. стварањем одговарајућих фемининатива, али и формирањем именовања експресивног карактера, тј. пејоратива, или пак аугментатива са сублимираном позитивном оценом. 
Важно је напоменути да лексику која припада жаргону одликује висок степен експресивности. У ексцерпираном материјалу могу се наћи и лексеме без конотативних значења, које у својој структури садрже значење 'припадник одређене поткултуре’.

Анкетирање испитаника је вршено путем интернета. Испитаници су попуњавали табелу у којој су имали понуђене називе музичких жанрова поред којих су могли да наведу именовања за припадника и припадницу одређене музичке поткултуре, две посебне колоне у којима су могли да наведу образовања експресивног карактера (позитиван однос и негативан однос према припаднику/припадници одређене музичке поткултуре), као и посебну колону у којој су могли да оставе коментар у вези са одређеном лексемом. Испитаници су имали могућност и да допуне табелу њима познатим музичким жанровима и одговарајућим именовањима за припаднике поткултура. У сваком од три дела анкете (српском, руском и пољском) учествовало је по шест изворних говорника узраста од 18 до 34 године. Познато је да жаргон може да буде и територијално условљен (Бугарски 2003: 9), те су испитаници били из различитих градова (у српском делу анкете учествовали су испитаници из Београда, Зрењанина, Новог Сада и Сомбора, у руском делу испитаници из Архангелска, Москве, Нижњег Новгорода и Санкт Петербурга, док су у пољском делу учествовали испитаници из Бидгошча, Варшаве, Вроцлава и Познања).

\section{2. УВОДНА РАЗМАТРАњА}

Лексика, која је предмет анализе овог рада, припада музичком сленгу или аргоу (чешће жаргону), који подразумевају супстандардни слој с обавезном компонентом афективности и пејоративности (Клајн 1996: 79). У монографији Жаргон: лингвистичка студија жаргоном се назива „сваки неформални и претежно говорни варијетет неког језика који служи за идентификацију и комуникацију унутар неке друштвено одређене групе - по професији, социјалном статусу, узрасту и слично - чије чланове повезује заједнички интерес или начин живота" (Бугарски 2003: 9). Услед широког обима овог одређења Ранко Бугарски (2003: 10) предлаже поделу на стручни, субкултурни и омладински тип жаргона. Лексика анализирана у овом раду припада субкултурном, али и омладинском типу жаргона, пошто оштре границе међу њима не постоје, па се субкултурни жаргони често стапају са омладинским (Бугарски 2003: 11). Иако и сам Бугарски (2003: 12) примећује да се за поједине жаргоне, поготово оне са друштвене маргине, чешће користе термини арго или сленг, он предност даје термину жаргон, који обухвата различите неформалне типове језичког варијетета. Исти термин користи и Зорица Кнежевић у монографији Човек у Жаргону: семантичко-деривациона анализа жаргонизама са архисемом човек. Ауторка путем семантичке и деривационе анализе покушава да утврди шта се и на који начин подвргава жаргонизацији и разврстава прикупљене речи према полу, старости, физичким карактеристикама, према социјалном статусу и занимању означеног појма. У поглављу посвећеном анализи именовања особа мушког пола издвојена је група од 15 именовања са обележјем '(мушка особа + социјална улога + статус) + однос премА музици’ (Кнежевић 2010: 50). У посебном поглављу врши се деривациона анализа прикупљених именовања. 
Од изузетне важности за компаративно истраживање музичког жаргона је монографија Музички жаргон младих и Молодежный музыкальньй сленг: компаративни поглед Софије Милорадовић из 2012. године, која се бавила музичким жаргоном са аспекта творбене и лексичко-семантичке анализе, а на чије резултате и запажања смо се вишеструко освртали током овог истраживања. Дериватолошко-лексиколошким истраживањима руског и српског језика бавила се и Јелка Матијашевић, али су се дата истраживања најчешће вршила на материјалу стандардног језика. Адаптацијом позајмљеница у руском и српском језику које припадају жаргону Матијашевић (2019) се бавила у раду Творбени механизам у функиији адаптације позајмљене лексике из 2014. године. У датом раду је указано на мали број лексема, које припадају музичком жаргону (нпр. фолкерка, рокерка).

Приликом именовања припадника других поткултура користи се експресивна, а врло често и пејоративна лексика. Експресивима, у оквиру којих су и пејоративи, бавила се Стана Ристић, а њена дугогодишња истраживања су обједињена у научној монографији Експресивна лексика у српском језику (теоријске основе и нормативно-културолошки аспекти). У датом истраживању ауторка подсећа на променљивост експресивне лексике, чија се динамика испољава у неутрализацији постојећих конотатива и у стварању нових. Одређивање лексичких јединица као експресива је релевантно, што је условљено узрастом, нивоом културе, социјалним статусом испитаника у психолингвистичким истраживањима (Ристић 2004: 19).

Веома значајна за истраживање пејоративних деривата којима се именује човек у српском језику је и докторска дисертација Јоване Б. Јовановић Лексика погрдног значења у именовању човека у српском језику, одбрањена на Филолошком факултету Универзитета у Београду 2018. године.

Нестандардна лексика је предмет многобројних истраживања и лексикографских подухвата у русистичкој и полонистичкој научној средини. Термини жаргон, арго и сленг се у русистичкој литератури веома често смењују у различитим временским периодима, понекад чак и код истог аутора, а некада се користе и синонимично (Милорадовић 2012: 43). Приликом ексцерпције руске жаргонске лексике за потребе овог истраживања коришћен је речник Молодежный сленг. Толковый словарь. Около 20000 слов и фразеологизмов Т. Г. Никитине, која преферира употребу термина сленг (Милорадовић 2012: 44). Овом приликом навешћемо само нека од имена у руској стручној литератури која су се бавила жаргоном: Д. С. Лихачов (Д. С. Лихачев), Ј. А. Земска (Е. А. Земская), В. С. Јелистратов (В. С. Елистратов), В. В. Химик (В. В Химик) и други (Милорадовић 2012: 42-43). У полонистичким радовима посвећеним нестандардној лексици често се истичу имена лингвиста и лексикографа Ј. Бралчика (J. Bralczyk), В. Лубаша (W. Lubaś), М. Чешевског (M. Czeszewski), А. Малоха-Крупе (А. Małocha-Krupa) и других. У полонистици постоји дуга традиција проучавања и дефинисања нестандардне лексике, али је однос према проучавању нестандардног језика до 1989. године био негативан. И у полонистици је присутна терминолошка неуједначеност (slang, żargon, argot, gwara) (Rabczuk 2017: 110-114).

У другој половини XX и почетком XXI века омладина се уз различите тенденције у свакој од земаља, у којима се говоре у овом раду анализирани 
језици, груписала у одређене поткултуре. Мартић (2013: 88) поткултуру посматра као скуп норми, вредности и образаца понашања који диференцирају једну групу људи у односу на културу шире заједнице. Коковић (1997: 34) сматра да поткултура није изолована у односу на владајућу културу, већ да је она само релативно заокругљена. Испитивањем идентитета који се обликују у оквиру омладинских поткултурних група и повезивањем идентитета са поткултурним стиловима у својим истраживањима бавио се Никола Божиловић (2009, 2010). Божиловић (2010: 45) сматра да се поткултурни идентитет симболички представља кроз имиџ, музику и жаргон, чиме се одбија доминантна култура и друштвене конвенције. У своме раду он се ослања на многобројна истраживања социјолога, који потврђују директну везу између музичког укуса појединца и његове припадности одређеној поткултури (Божиловић 2010: 56-57). Зато није ни чудно што највећи део назива за поткултуре настаје управо од назива музичких праваца (или музичких група), најчешће суфиксацијом (срп. металщи). У нешто мањој мери именовања за припаднике поткултура настају од других речи, које би могле да се асоцирају са начином живота и стилом облачења (срп. дизелаши од модне марке Diesel (Gordy 2010: 133); пољ. dresiarze мотивисано речју dres (тренерка); рус. кислотники мотивисано жаргонским називом за дрогу кислота (Милорадовић 2012: 135-136).

Највећи број именовања који се анализира је неутралан, док мањи број представљају експресивне именице претежно са негативном, пејоративном оценом (нпр. Уважсаю сатанистов, панков, готов разного вида... рэпитосы и гопы - отбросы общества !1).

У ексцерпираном материјалу срећу се и примери када одређена именовања у контексту могу да имају и позитивну оцену. У том случају најчешће чланови исте поткултуре потврђују да је лице које се именује датом лексемом „пра̂ви“ или „репрезентативан“ припадник одређене поткултуре. Наравно, уколико одређени припадници поткултуре користе одређену лексему за аутономинацију, можемо претпоставити да је та лексема без конотативне компоненте.

\section{1. СРПСКИ ЈЕЗИК}

Као што је Милорадовић (2012: 50) приметила у свом истраживању, велики део ове лексике се попуњава позајмљивањем из страних језика (пре свега из енглеског). Ипак, у последњем електронском издању речника новијих англицизама Du yu speak anglosrpski (Васић и др. 2018) постоји само 8 примера (денсер (64), хевиметалаи (112), рокер, рокерка (207), рејвер (200), репер, реперка (202), скинер (222)).

Претрагом на интернету, анкетирањем говорника српског језика, али и ексцерпирањем примера из Београдског фрајерског речника, Речника српскога језика Матице српске, горепоменутог речника Du yu speak anglosrpski и монографије Музички жаргон младих и Молодежный музыкальный сленг: компаративни поглед (2012: 79) прикупљена је 81 лексема: алтернативаи, алтернативка, блузер, блузерка, брејкер, брејкерка, готичар, готичарка, готкиња, граниер, граниерка, дабстепер, денсер, денсерка, дизелаш, дизелашииа, турбофолкер, турбофолкер-

\footnotetext{
${ }^{1}$ Сви примери употребе лексема у контексту преузети су са интернета.
} 
ка, електрофрикови, емо, емашица, емовац, емос, емоскиға, косијанер, металаи, металка, металкиња, металика, металчина, народюак, народюакуша, панкер, панкерка, панкерчић, панкеруша, прљавац, растафаријанаи, растафаријанка, рокер, рокерка, рејвер, рејверка, рејверчина, рејвераш, репер, реперка, реперчина, реперчић, сељак, сељачина, сељобер, сељоберка, скејтер, скејтерка, скинс, скинер, скинерка, трепер, треперка, тресоглавач, технофрик, уберсељачина, фанкер, фанкерка, фенсер, фенсерка, фенсерчина, фенсеруша, фолкуша, хардкоровач, хаусовач, хипик, хипи, хипстер, хипстерка, хипстерчина, хипстерчић, хипстеруша, хип-хопер, хипхоперка.

У прикупљеном материјалу издвајају се следећи суфикси који учествују у деривацији именовања за припаднике одређене музичке поткултуре: $-\bar{a} \kappa /-j \bar{a} \kappa,-a u$, -ијан( $)$ u, -ик, -јар (могуће: -ар или -ичар), -ов(а)ч и -ер.

Суфикс $-\bar{a} \kappa /-j \bar{a} \kappa$ се додаје на придевске основе, а изведеница обележава биће или предмет који поседује особину изражену придевом (Клајн 2003: 31-32). У српском језику устаљен је израз народна музика, те се од придева народни твори народњак који може да има значења: (1) народне песме, (2) извођача народне музике, али и (3) поштоваоца народне музике (најчешће у множини) ${ }^{2}$. Мањи број изведеница са овим суфиксом је од именичке основе, а у ексцерпираном материјалу се среће један пример - сељак.

Суфикс -ац се среће код лексема које су настале од именица (алтернативац, металац), придева (прљавац) и сложенице (тресоглавац). Облик металац је и раније постојао у српском стандардном језику, али у значењу 'радник у металској индустрији', које потврђује Речник српскога језика. У жаргону металац означава 'поклоника металске музике'. Пример настао од придева прлав припада експресивима пејоративног карактера, пошто је негативан став говорника изражен у основи. Ово именовање се образлаже прљавом одећом и косом, која се везује за рокере, металце и панкере. Тресоглавац представља калк композит из енглеског headbanger и међу испитаницама нисмо наишли на потврду овог облика, али се он среће у интернетској комуникацији за пејоративно именовање рокера, металаца и панкера.

Проширени суфикс -ијан(a)u се најчешће додаје властитим именима. Највероватније је да представља адаптацију енглеског -ian (Клајн 2003: 58-59) и среће се код једне лексеме: растафаријанац.

Проширени суфикс -ов $(a)$ u̧ се среће код лексема хардкоровац и хаусовац. Ови примери иду у прилог тврђењу Клајна (2003: 55) да се овај суфикс делимично осамосталио, пошто су именице хардкоровац и хаусовац изведене од именица хардкор 'правац у панк музици' и хаус 'музички правац’

Лексема готичар по начину деривације подсећа на лексеме критичар и математичар око којих се водила полемика међу лингвистима да ли у њиховој деривацији учествује суфикс -ичар, -јар или -ар (Клајн 2003: 43). Назив овог жанра музике је готик-рок, али у српском језику је пре појаве овог музичког правца постојала лексема готика, која означава правац у архитектури и умет-

\footnotetext{
${ }^{2}$ Упоредимо следеће примере: (1) Народњак и то какав! Семир Јахић објавио тизер нове песме; (2) Како је Шабан Шаулић за нас рођене седамдесетих постао једини народњак коме се истински клањамо; (3) На юу и народюаци и рокери секу вене!
} 
ности. Претпостављамо да је реч готичар мотивисана управо именицом готи$\kappa a$, по аналогији са образовањима насталим од именица критика и математика (критичар, математичар).

Суфикс -ер је страног порекла (разликују се два: један с кратким $е$ из немачког и енглеског, други са постакценатском дужином од француског -eur, али се они тешко разграничавају) и најчешћи је творбени формант у ексцерпираном материјалу. Изведенице са суфиксом -ер означавају човека, вршиоца радње, па се овај суфикс додаје на глаголске основе (Клајн 2003: 228-229). Ипак, суфикс -ер се среће и уз именичке основе код англицизама (брејкер, граниер, дабстепер, денсер, панкер, рокер, рејвер, скејтер, хипстер). Ове лексеме се могу посматрати и као фонетски прилагођене позајмљенице. Као творбени модел суфикс -ер се среће код псеудоанглицизама, тј. лексема које су настале суфиксацијом (блузер, турбофолкер ${ }^{3}$, скинер, трепер ${ }^{4}$, фанкер, фенсер).

Суфиксом -ик, који је грчког порекла и односи си се на људе и означава припадност (Клајн 2003: 237), у ексцерпираном материјалу твори се само лексема хипик.

У прикупљеном материјалу фемининативи су грађени помоћу следећих суфикса: -ица , -ка, -киња.

Помоћу суфикса -ища гради се фемининатив дизелашщщ̧а. По аналогији је вероватно настала и емашица, иако не постоји маскулинум *емаш.

Помоћу суфикса -ка формирани су фемининативи типа: алтернативка, блузерка, брејкерка, готичарка, гранцерка, денсерка, турбофолкерка, металка, панкерка, рокерка, рејверка, реперка, сељоберка, скејтерка, скинерка, трепер$\kappa a$, фанкерка, фенсерка, хипстерка. Не треба заборавити да је велики број фемининатива настао додавањем суфикса -ка на облик за маскулинум, од којих су неки фонетски прилагођене позајмљенице, док су други настали помоћу суфикса -ер. Мањи је број примера где се суфикс -ка додаје директно на основу (алтернативка, металка).

Помоћу суфикса -кињ $а$ творе се лексеме додавањем на маскулинум емоскињ $а$, реперкиња или директно на основу металкињ $а$. Образовање са -киња од основе гот формира лексему Готкињ, која означава припадницу народа Гота, а реч готичарка се специјализовала у значењу припаднице поткултуре. Ипак, на интернету се могу наћи и примери у којима је готкиња употребљена у значењу 'припадница готичарске поткултуре', али далеко ређем.

У прикупљеном материјалу издвајају се следећи суфикси за образовање ек-

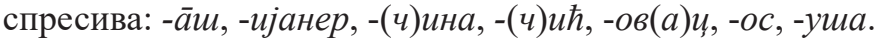

${ }^{3}$ У енглеском постоји само лексема folker са значењем извођач фолк музике.

${ }^{4}$ У енглеском је trapper само извођач треп музике. У српском примеру преузетом са интернета, ипак, може да се односи и на припадника поткултуре (нпр. Pa to je kao popularna muzika i mainstream, ali verujem da se tu nije promenilo mnogo od mojih gimnazijalskih dana od pre 15 godina... Imao si mainstream ekipu, pa one old school kafana narodnjake, pa repere (danas su to treperi klinci vole domace $i$ strane), i rokeri raznih fela. Pankeri su tada već izumirali, bilo ih je malo verujem danas još manje, ali sigurno ima metalaca dosta, pa slušaju standardno stare bendove.. Među rokerima ima verovatno danas dosta i hipstera, i alternativaca, jer je i naša scena dosta jaka... [изворна ортографија преузета са интернета]). 
Суфикс -а̄u се среће код жаргонизама, којима се означавају особе мушког пола, а сасвим ретко и делови тела (Кнежевић 2010: 143). У прикупљеном материјалу срећемо га код лексема дизелаш, која је мотивисана карактеристичним предметом, тј. марком одеће, и рејвераш, код које се суфикс -а̄u додаје на позајмљеницу рејвер, и има експресивни карактер.

Лексема косијанер може да се односи на љубитеље метал и рок музике. Настала је помоћу жаргонског суфикса -ијанер, за који Клајн (2003: 236-237) сматра да је маргинална и ефемерна појава, и да би изведенице тог типа морале да прођу кроз лексикографску обраду, пре него што постану предмет изучавања у творби речи.

Помоћу аугментативног суфикса -(ч)uна стварају се лексеме експресивног карактера које могу бити лексеме позитивне оцене, што нам потврђује контекст (нпр. Ко је овде највећа рејверчина?; Емси Стојан је реперчина за њега!; Стога што сам стара металчина у души!). Ипак, такве лексеме се могу сретати и у контекстима у којима се изражава негативан однос према припадницима одређене поткултуре (нпр. Мени је то одвратно, налицкано фенсерчина права; Брат ми је огавна хипстерчина; ...ове металчине су стварно најгори шљам!). Лексема сељачина се најчешће користи као пејоративно именовање припадника поткултуре која излази у клубове, на сплавове и у дискотеке у којима се слуша турбофолк музика, али може да се односи и на било коју особу, која се не понаша у складу са нормом или онако, како то очекује говорник у некој од ситуација (нпр. у саобраћају). Лексема металчина обележава и металску музику, или тврђи звук на свирци.

Проширени деминутивни суфикс -(ч)uћ функционише као фонетска варијанта од $-u \hbar$. Суфикс - $(4) u \hbar$ се најчешће спаја са основама са завршетком на $-н,-л,-p$. Међу основама на - $p$ преовлађују називи људи, где деминутив добија експресивно значење ниподаштавања и сажаљења (Клајн 2003: 111) (панкерчић, реперчић, хипстерчић).

Деминутивни и аугментативни суфикси дају значење субјективне оцене говорника: негативне оцене за именовање представника одређене поткултуре $(\mathrm{OH}$ је обичан хипстерчић/обична хипстерчина) или позитивне, у случају именовања репрезентативног припадника пожељне поткултуре (Он је права реперчина).

Припадник емо поткултуре се у српском најчешће назива емос. Страни флективни наставак -ос је шпанског порекла (према гаучо, гаучоси) и код нас се схвата као део основе и тако настаје жаргонски суфикс -ос (нпр. najmoc, peтос, дебос, хомос). У претрази на интернету сусреће се и облик емовац.

Помоћу суфикса -уша творе се пејоративни облици за припаднице поткултура, као што су народњакуша, панкеруша, фенсеруша, фолкуша, хипстеруша.

Следећи називи припадника поткултура представљају фонетски прилагођене лексеме позајмљенице из енглеског језика: електро-фрик, емо, техно-фрик, хипи. Овом низу можемо додати и фонетски прилагођење лексеме из енглеског језика, које су настале помоћу суфикса -er (рокер према енглеском rocker). Потребно је обратити пажњу и на двојако значење лексеме техно-фрик. У српском жаргону се среће у значењу 'људи који слушају техно музику' (нпр. Стари рокери су оно, будимо благи, симпа; Техно-фрикови су дефинитивно 
шизофренични аутсајдери) и 'страствени љубитељи технологије' (нпр. ...али то су опичије које не интересују љубитеље телефона, већ технофрикове), у односу на енглеску реч techno-freak која означава само особу која је страствени љубитељ технологије.

Лексема металика се најчешће користи у пејоративном значењу (нпр. Закључили су како текстови хеви метал музике деиу неће претворити у «оштећену робу» нити у «прљаве металике», као ито то тврде многи). Претпостављамо да она није настала суфиксацијом помоћу суфикса -ика, што потврђује став Душанке Вујовић (Клајн 2003: 88), која сматра да су називи за лица и животиње толико непродуктивни да су изведенице са суфиксом -ика скоро изгубиле сва та значења. Из истих разлога претпостављамо да је лексема металика у значењу 'поклоник металске музике, али и других алтернативних музичких праваца', настала од назива групе Металика.

Сви информанти, за шта имамо потврду у примерима прикупљеним путем интернетске претраге, именовало је људе који слушају фолк музику лексемама пејоративног значења сељак, сељачина, сељобер ${ }^{5}$, сељоберка итд. Оваква именовања су мотивисана метонимијским моделом (ПРостор/МЕСТо $\rightarrow$ човеК КОЈИ БОРАВИ/ЖИВИ НА ЊЕМУ), у садејству са метафором индукованом колективном експресијом (Јовановић 2018: 214). Среће се образовање са фонетским прилагођеним формантом у првом делу сложенице уберсељачина 6 и аугментативним суфиксом.

\section{2. РУСКИ ЈЕЗИк}

Приликом ексцерпирања материјала за руски језик користили смо речнике Молодежный сленг. Толковый словарь. Около 20000 слов и фразеологизмов, Большой универсальный словарь русского языка, Словарь-справочник по материалам прессы и литературы 90-х годов, Словарь англицизмов русского языка, монографију Музички жаргон младих и Молодежный музыкальный сленг: компаративни поглед (2012: 110-111), али и интернетску претрагу и анкетирање информаната. Прикупљене су 83 лексеме: альтернативщчик, альтернативщиияа, брейкер, брейкерша, брейк-дансист, брейкист, брейк-танцуор, габбер, говнарь, гот, готка, готарь, готесса, гранжер, дабстепер, дабстеперша, дансер, дансерша, думер, эмо, эмарь, эморас, эмоист, эмоистка, эмочка, эмо-бой, эмогёрл, эмо-киды, индустриальщики, кенти, кислотник, кислотница, металлер, металлерша, металлист, металлистка, металлург, металлюга, металхэды,

${ }^{5}$ Могуће је да је именица сељобер настала по узору на сложенице биљобер, бувобер, винобер, класобер.

${ }^{6}$ Од страних префикса у деривацији пејоратива за именовање човека често се среће немачки формант обер-, чије је значење '(из)над-' и употребљава се као први део именичких сложеница који означава виши чин или положај онога што означава други део сложенице: обервојвода, оберкоманда, оберкелнер и др. Међутим, у спојевима са именицом негативног експресивног значења реализује се иронична, погрдна конотација, односно, додатно се истиче већ постојећа пејоративна компонента алузијом на то да је именована особа 'изнад свих осталих у у поседовању негативне особине или репрезентовању непожељног владања (Јовановић 2018: 575-576). 
метлист, мэггот, нью-вейвщик, (наци-)панк, панкист, панкистка, панкушка, панкуха, пипл, пипла, пипляк, попсушник, попсушница, растаман, растаманка, растафарианец, растафарианка, рокер, рокерша, рейвер, рейверша, рэпер, рэперша, рэпарь, рэпитос, скашник, скашница, ска, скейтер, скейтерша, скин, (начи-)скинхед, скинша, стрейтэйджер, трэпер, трэшер, хардкорщик, хардюшник, хиппан, хиппарь, хиппи, хипстер, хипстерша, хипстерюга.

У руском анализираном материјалу издвајају се следећи суфикси у именовањима припадника поткултура: -ер, -ианец, -ист, -иник, -шиик.

Као и у српском језику, један од најчешће коришћених форманата је суфикс -ер (брейкер, габбер, дабстепер, дансер, металлер, рокер, рейвер, рэпер, скейтер, стрейтэйджер, трэпер, трэшер, хипстер). Ипак, треба имати у виду да велики део ових лексема може да представља фонетски прилагођене лексеме из енглеског језика. Изузетак би биле лексеме металер и трэпер, које са суфиксом -er не постоје у енглеском језику, као и лексема стрейтэйджер, пошто се у енглеском језику правилнијим сматра облик без суфикса -er (straight edge).

Суфикс -ианец среће се у лексеми растафарианец.

Веома продуктивним суфиксом показао се и суфикс -ист (брейк-дансист, брейкист, эмоист, металлист, метлист, панкист).

У жаргону је веома продуктиван и суфикс -шник. У нашем корпусу наишли смо на један пример - скашник. Булавина (2011: 101-105) је указивала на важност овог суфикса приликом грађења речи од скраћеница. Не зна се са сигурношћу порекло назива правца у музици ска, али могуће је да је због сличности са скраћеницама дошло до процеса суфиксације назива овог музичког правца по аналогији са образовањима од скраћеница (нпр. гаишник).

Суфикс -щцик среће се у лексемама альтернативщик, индустриальщъики, нью-вейвщчик и хардкорщцик.

Најпродуктивнији суфикси за формирање фемининатива у руском материјалу су суфкиси -иа (брейкерша, дабстеперша, дансерша, металлериа, рокериа, рейверша, рэперша, скейтерша, скинша, хипстерша), -ка (готка, металлист$\kappa a$, растаманка) који се додају директно на маскулинум. Фемининатив растафарианка настаје од маскулинума растафарианец.

Веома је продуктиван и суфикс -ищ̧а (альтернативщцича, кислотнищฺа, nоnсушница, скашница).

Суфикс страног порекла који се сматра непродуктивним (Ефремова 1996: 138) -есса твори лексему готесса.

Суфикс -ушка срећемо у једној лексеми - панкушка (фемининатив), суфикс -yxа такође у једној изведеници - панкуха (коју су испитаници навели у значењима 'припадник панк поткултуре', 'припадница панк поткултуре' и 'врста музике', а потврду за њих смо пронашли и у другом тому речника Новые слова и значения: словарь-справочник по материалам прессы и литературы 90-х годов ХХ века.

Помоћу форманата -ан, -ар', -итос, -ник, -уга (-юга), -ушник (-уха + -ник), -як добијене су лексеме са експресивним значењем.

Суфикс -ан се среће у једном примеру у ексцерпираном материјалу - хиппан. Овај суфикс сматра се непродуктивним (Ефремова 1996: 38-42) 
Суфикс - $a p$ ' је веома продуктиван у ексцерпираном материјалу (говнарь, гоmapb, эмарь, pэnарь, хиппарь). Лексема говнарь означава припадника рок поткултуре и има пејоративан карактер.

Претпостављамо да је лексема рэпитос добијена спајањем основе pen са -итос афективним и деминутивним суфиксом из шпанског -ito са флективним наставком за множину, који се у руском доживљава као основа.

Суфиксом -ник твори се лексема кислотник од жаргонског назива кислота за врсту дроге, која се везује за начин живота поклоника рејвова.

Суфикс -уга (-юга) у ексцерпираном материјалу срећемо само у примерима металлюга, хипстерюга, рэперюга који представљају стилски снижене синониме лексема металлист, металлер, хипстер, рэпер.

Што се тиче лексема попсушник, хардюшник Милорадовић (2012: 113) наводи став Химика да је могуће да се овде ради о преклапању два форманта -yxa и -ник и да су ови примери емотивно-експресивно обележени.

Суфикс -як, који се сматра непродуктивним (Ефремова 1996: 38-42) среће се у примеру пипляк, који означава припадника хипи поткултуре.

Велики број лексема представља фонетски прилагођене позајмљенице из енглеског језика (эмо, эмо-бой, эмо-гёрл, эмо-киды, кент, ска и др).

\section{3. ПОљСКИ ЈЕЗИК}

Приликом прикупљања пољског материјала коришћен је Maty stownik subkultur młodzieżowych (Pęczak 1992), Miejski słownik slangu i mowy potocznej, интернетска претрага, али су и анкетирани говорници пољског језика. Приликом анкетирања испитаници су изражавали недоумицу приликом грађења ових облика, а приликом претраге на интренету примећен је мали број примера употребе одређених лексема, те се оне могу сматрати и оказионализмима. У пољском материјалу је специфичан двојак начин писања основа од којих је настала изведеница: транскрибована основа или основа преузета из енглеског језика без прилагођавања. Прикупљено је следећих 60 лексема: alternatywka, breakdancowiec (ретко ${ }^{7}$ ), brekdensiara (ретко), brudas, got, gotka, dupstepowiec (ретко), discopolowiec, discopolówa (ретко), diskomut, depesz, depeszowiec, depeszówa, emo, grandżowiec, grandżówa, hip-hopowiec, hip-hopówa, metalowiec, metal, metalówa, metalówka, punk, pank, punkowiec, punkówa, streetpunkowiec, ojowiec, streetpunkówa, ojówka, rastaman, rastamanka, rockowiec, rockman, rockmen, rockmenka, rockmanka, raveowiec, raper, raperka, raperzyna, skejt, skate, skater, deskorolkowiec, skaterka, deskorolkówa (ретко), skinhead, skin, skinheadka, trashowiec, traszowiec, technowiec, technoman, technomanka, technomut, hipis, hipiska, hipster, hipsterka.

У прикупљеном материјалу најпродуктивнији суфикс за творбумаскулинумаје -owiec (16 примера). Издвојићемо пример depeszowiec који има значење 'љубитељ музичког састава Depeche Mode'.

${ }^{7}$ Испитаници су били у могућности да напишу да се одређена лексема ретко употребљава. Ипак, у раду смо наводили све лексеме за које смо нашли потврду током интернетске претраге и у речницима. 
Фемининативи се у прикупљеном материјалу творе помоћу суфикса -ówa и -ka, нешто ређе помоћу -ówka. Изведенице настале помоћу суфикса -ówa често означавају и музику (traszówa, technówa).

Суфикс -arz чешће иде уз именичке основе (Masojć 2015: 24), а у нашем ексцерпираном материјалу наишли смо на пример dresiarz. Назив за припадника поткултуре мотивисан је речју dres (срп. тренерица), пошто је одлика припадника дате поткултуре ношење тренерица. Ово је аналогно пољском kawiarz, које означава 'човека који воли и/или често пије кафу'.

Суфикс -as ce у пољској литератури сматра непродуктивним и експресивним формантом (Masojć 2015: 56). Среће се у примеру brudas, који се односи на рокере, металце, панкере, а настао је од придева brudny „прљав”. Формирањем овог облика дата особина се приписује припадницима одређене групе као њихово константно обележје и она је пејоративног карактера.

Суфикс -ina/-yna смо у ексцерпираном материјалу нашли само код образовања raperzyna, и ова реч има пејоративни карактер (нпр. Mes postanowit bowiem dowieść światu, że nie jest jakimś tam raperzyna, ale prawdziwym artysta niezależnym).

У двоименички тип композита (именица + именица) можемо сврстати две лексеме technomut и diskomut, које имају пејоративни карактер (нпр. problemy ze spaniem spowodowane tym, że jakiś DiskoMut napierdziela za ściana muzę w rytm określenia siebie samego - buc buc buc!), а настале су према моделу пољске речи ostomut, која означава мазгу.

Велики је број фонетски прилагођених позајмљеница из енглеског (got, metal, punk, pank, skejt, skate и др.). Занимљиво је да се код именовања за припадника рокерске поткултуре код пољских испитаника, поред образовања rockowiec, у једнини појављује и облик rockman, док се у множини појављује облик rockersi. Приликом претраге на интернету у косим падежима у једнини, као и у свим падежима у множини среће се основа проширена страним флективним наставком за множину (нпр. On jest rockersem; Rockersi sa najmilszymi ludźmi dla fogografów; Jesteśmy rockersami), као и образовање rockman (нпр. On jest rockmanem; Najlepiej sprzedajacy się rockmani). У номинативу једнине смо срели само образовање rockman (нпр. ...jej chłopak rockman też).

\section{4. ЗАКљУЧАК}

На прикупљеном материјалу спроведена је деривационо-семантичка анализа жаргонизама за именовање припадника и припадница различитих музичких поткултура и утврђени су начини њихове творбе у српском, руском и пољском језику. Међу анализираном лексиком налазе се лексеме са денотативним значењем 'припадник или припадница музичке поткултуре', али и лексеме које су експресивног карактера и указују на позитиван и негативан став говорника према припадницима и припадницама музичких поткултура. За жаргонизме је карактеристично то да су променљивог карактера и да врло често на њихову експресивност утицај имају психолингвистички фактори (нпр. узраст и социјални статус говорника). Најчешће су именовања за припаднике и припаднице поткултура мотивисана називом музичког жанра. 
Најпродуктивнији суфикс у српском и руском језику за формирање именовања за припадника музичке поткултуре или љубитеља музичког правца је суфикс страног порекла -ер. Треба обратити пажњу да је међу прикупљеним лексемама велики број оних које се могу посматрати као позајмљенице из енглеског језика. Међу домаћим неутралним суфиксима издвајају се суфикси -ац и проширени суфикс -ов $(a)$ u. У руском се као продуктиван показао и суфикс -ист. Најпродуктивнији суфикс за формирање маскулинума у прикупљеном материјалу за пољски језик је суфикс -owiec. Приликом формирања фемининатива у српском је најзаступљенији формант -ка, док је у руском суфикс -ша, а у пољском -ówa. Функцију експресивности у српском језику имају -āu, -(ч)

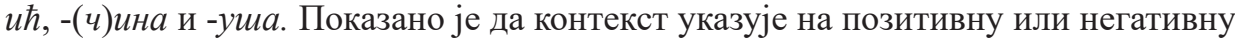
оцену говорника код експресивних образовања са аугментативним суфиксом (ч)ина. У руском функцију експресивности имају суфикс -уга, -yхa, -ушник, а у пољском суфикс -as. У свим анализираним језицима примећен је велики број фонетски прилагођених позајмљеница из енглеског језика.

Примену овог истраживања пре свега видимо у лексикографији. Бугарски (2003: 11) примећује да се жаргон, који се устаљује у општој употреби, може преко разговорног језика прелити у стандардни језик. У прикупљеном материјалу велики је број лексема за које можемо рећи да имају чисто денотативно значење (припадник/припадница одређене поткултуре), али се оне врло често не налазе ни у речницима супстандардне лексике. Сасвим очекивано, такве лексеме су реткост у једнојезичним речницима стандардног српског, руског и пољског језика. Уколико се дате лексеме ипак налазе у речницима жаргона, врло често су представљени само облици маскулинума.

Надамо се да ће овај рад дати идеју за даља и темељнија дериватолошка истраживања жаргонског подсистема српског, руског и пољског језика, али и да ће служити као подстицај за њихову темељнију лексикографску обраду.

\section{Цитирана литература}

Бугарски, Ранко. Жаргон: лингвистичка студија. Београд: Библиотека XX век : Књижара Круг, 2003.

[Bugarski, Ranko. Žargon: lingvistička studija. Beograd: Biblioteka XX vek : Knjižara Krug, 2003]

Булавина, Наталья В. «Особенности словообразования отсубстантивных конкретных одушевлённых имён существительных (на материале СМИ)». Ученые записки Орловского государственного университета. Серия „Гуманитарные и социальные науки”, № 2, 2011: 101-105.

[Bulavina, Natal'iā V. «Osobennosti slovoobrazovaniiā otsubstantivnykh konkretnykh odushevlënnykh imën sushchestvitel'nykh (na materiale SMI)». Uchenye zapiski Orlovskogo gosudarstvennogo universiteta. Seriia „Gumanitarnye i sotsial'nye nauki”, № 2, 2011: 101-105]

Ефремова, Татьяна Ф. Толковый словарь словообразовательных единиц русского языка. Москва: Русский язык, 1996.

[Efremova, Tat'iâna F. Tolkovyı̌ slovar' slovoobrazovatel'nykh edinits russkogo iâzyka. Moskva: Russkiǔ iāzyk, 1996] 
Јовановић, Јована Б. Лексика погрдног значења у именовању човека у српском језику [докторска дисертација]. Београд, 2018.

[Jovanović, Jovana B. Leksika pogrdnog značenja u imenovanju čoveka u srpskom jeziku [doktorska disertacija]. Beograd, 2018]

Клајн, Иван. „Сленг“. [У:] М. Радовановић (ред.) Српски језик на крају века, Београд: Институт за српски језик САНУ - Службени гласник (Краљево: Слово), 1996, 79-81.

[Klajn, Ivan. „Sleng“. [U:] M. Radovanović (red.) Srpski jezik na kraju veka, Beograd: Institut za srpski jezik SANU - Službeni glasnik (Kraljevo: Slovo), 1996, 79-81]

Клајн, Иван. Творба речи у савременом српском језику, II део - Суфиксација и конверзија. Београд: Завод за уџбенике и наставна средства - Институт за српски језик САНУ - Нови Сад: Матица српска, 2003.

[Klajn, Ivan. Tvorba reči u savremenom srpskom jeziku, II deo - Sufiksacija i konverzija. Beograd: Zavod za udžbenike i nastavna sredstva - Institut za srpski jezik SANU - Novi Sad: Matica srpska, 2003]

Коковић, Драган. Пукотине културе. Београд: Просвета. 1997.

[Koković, Dragan. Pukotine kulture. Beograd: Prosveta. 1997]

Матијашевић, Јелка. Творбени механизам у функцији адаптације позајмљене лексике. [У:] В. Васић, М. Стефановић (ред.). Дериватолошко-лексиколошка истраживања руског и српског језика : зборник радова Јелке Матијашевић, Нови Сад : Филозофски факултет, 2019.

[Matijašević, Jelka. Tvorbeni mehanizam u funkciji adaptacije pozajmljene leksike. [U:] V. Vasić, M. Stefanović (red.). Derivatološko-leksikološka istraživanja ruskog i srpskog jezika : zbornik radova Jelke Matijašević, Novi Sad : Filozofski fakultet, 2019]

Милорадовић, Софија. Музички жаргон младих и Молодежный музыкальный сленг: компаративни поглед. Београд: Етнографски институт САНУ, 2012.

[Miloradović, Sofija. Muzički žargon mladih i Molodežnый muzыkalьnый sleng: komparativni pogled. Beograd: Etnografski institut SANU, 2012]

Ристић, Стана. Експресивна лексика у српском језику (теоријске основе и нормативно-културолошки аспекти). Београд: Институт за српски језик САНУ, 2004.

[Ristić, Stana. Ekspresivna leksika u srpskom jeziku (teorijske osnove i normativno-kulturološki aspekti). Beograd: Institut za srpski jezik SANU, 2004]

Božilović, Nikola. Izvan glavnog toga: sociologija muzičkih potkultura (Out of the Mainstream: The Sociology of Musical Subcultures). Niš: Niški kulturni centar, 2009.

Božilović, Nikola. „Youth Subcultures and Subversive Identities“. Facta Universitatis, Series: Philosophy, Sociology, Psychology and History. Vol. 9, No 1, 2010: 45-58.

Gordy, Eric D. Culture of Power in Serbia: Nationalism and the Destruction of Alternatives. University Park, Pennsylvania: Pennsylvania State University Press, 1999.

Knežević, Zorica. Čovek u žargonu: semantičko-derivaciona analiza žargonizama sa arhisemom čovek. Beograd: Alma, 2010.

Martić, Milomir V. „Omladinske potkulture i masovni mediji“. Svarog. br. 6, maj 2013. Br. 6. 2014: 88-104.

Masojć, Irena. Gramatyka współczesnego języka polskiego. Słowotwórstwo rzeczowników: skrypt dla studentów. Vilnius : Lietuvos edukologijos universiteto leidykla, 2015.

Rabczuk, Anna. „Sztuka nawijki, czyli jak uczyć cudzoziemców polskiego slangu młodzieżowego". Acta Universitatis Lodziensis. Kształcenie polonistyczne cudzoziemców. Vol. 24. 2017: 109-126. 


\section{Извори}

Буцева, Таисия Н., Евгений А. Левашов. Новые слова и значения : словарь-справочник по материалам прессы и литературы 90-х годов XX века. В 2-х томах (АК). Том 1, Ин-т лингвистических исследований РАН. - СПб.: Дмитрий Буланин, 2009.

[Butseva, Taisiiā N., Evgeniı̌ A. Levashov. Novye slova i znachenißa : slovar'-spravochnik po materialam pressy i literatury 90-kh godov KHKH veka. V 2-kh tomakh (A-K). Tom 1, In-t lingvisticheskikh issledovaniı̌ RAN. - SPb.: Dmitriǔ Bulanin, 2009]

Буцева, Таисия Н., Евгений А. Левашов. Новые слова и значения : словарь-справочник по материалам прессы и литературы 90-х годов XX века. В 3-х томах (Клиент-банк - Паркетный). Том 2, Ин-т лингвистических исследований РАН. СПб.: Дмитрий Буланин, 2014.

[Butševa, Taisiiâ N., Evgeniı̌ A. Levashov. Novye slova i znacheniîa : slovar'-spravochnik po materialam pressy i literatury 90-kh godov KHKH veka. V 3-kh tomakh (Klient-bank - Parketnyı̌). Tom 2, In-t lingvisticheskikh issledovaniı̌ RAN. - SPb.: Dmitriı̌ Bulanin, 2014]

Дьяков, Анатолий И. Словарь англицизмов русского языка. Новосибирск, 20142020. <http://anglicismdictionary.dishman.ru/Slovar> 10.03.2020.

[D'iakkov, Anatoliı̌ I. Slovar' anglitșizmov russkogo iāzyka. Novosibirsk, 2014-2020. $<$ http://anglicismdictionary.dishman.ru/Slovar $>10.03 .2020]$

Морковкин, Валерий В., Галина Б. Фёдоровна, Наталия М. Луцкая. Большой универсальный словарь русского языка. Гос. ин-т рус. яз. им. А. С. Пушкина. Москва: Словари XXI века, 2017.

[Morkovkin, Valeriı̌ V., Galina B. Fëdorovna, Nataliiā M. Lutskaiā. Bol'shoǐ universal'ny̌̌ slovar' russkogo iāzykka. Gos. in-t rus. iâz. im. A. S. Pushkina. Moskva: Slovari KHKHI veka, 2017]

Никитина, Татьяна Г. Молодежный сленг. Толковый словарь. Около 20000 слов и фразеологизмов. Москва: АСТ, 2009.

[Nikitina, Tat'iâna G. Molodezhnyǐ sleng. Tolkovyı̌ slovar'. Okolo 20000 slov i frazeologizmov. Moskva: AST, 2009]

Николић, Мирослав и др. Речник српскога језика. Нови Сад: Матица српска, 2011.

[Nikolić, Miroslav i dr. Rečnik srpskoga jezika. Novi Sad: Matica srpska, 2011]

Imami, Petrit. Beogradski frajerski rečnik: 6244 odrednica, 5701 fraza. Beograd: NNK International, 2003.

Miejski słownik slangu i mowy potocznej <https://www.miejski.pl/> 05.03.2020.

Pęczak, Mirosław. Mały słownik subkultur młodzieżowych. Warszawa: Semper, 1992.

Vasić, Vera, Tvrtko Prćić, Gordana Nejgebauer. Du yu speak anglosrpski? Rečnik novijih anglicizama. Treće, elektronsko, izdanje. Novi Sad: Filozofski fakultet, 2018. $<$ http://digitalna.ff.uns.ac.rs/sites/default/files/db/books/978-86-6065-451-1.pdf\#overlay-context=sadrzaj/2018/978-86-6065-451-1> 10.03.2020. 


\title{
Милорад Милякович
}

\author{
СПОСОБЫ СЛОВООБРАЗОВАНИЯ НАИМЕНОВАНИЙ \\ ПРЕДСТАВИТЕЛЕЙ МУЗЫКАЛЬНЫХ СУБКУЛЬТУР В СЕРБСКОМ, \\ РУССКОМ И ПОЛЬСКОМ ЯЗЫКАХ
}

\begin{abstract}
Резюме
На материале сербского, русского и польского языков в статье рассматриваются деривационные способы жаргонных образований-наименований представителей разных музыкальных субкультур (напр., серб: металаи; рус: металлист; поль: metalowiec/metal). Исследование проводилось на материалах одноязычных словарей стандартного языка, словарей сленга и текстов интернет-коммуникации. Часть исследования основывается на материалах опроса носителей сербского, русского и польского языков. Проведённый анализ показал, что во всех описанных языках при адаптации заимствованных слов, а также при формировании новых слов, задействованы словообразовательные механизмы суффиксации. Самым распространённым суффиксом для образования именований представителей музыкальных субкультур в сербском и русском языках является суффикс -еp, в польском суфикс -owiec. В статье также анализируются возможности и способы словообразования соответствующих феминитивов (напр. металлистка; серб. металка; поль. metalówka/metal/metalówa), пейоративов (напр. серб. реперчић/penерчина; рус. рэпитос; поль. raperzyna), и аугментативов, которые в определённых контекстах не имеют пейоративный характер, а представляют собой образования, передающие положительную оценку (напр., серб. Дадо, реперчино, уметниче, обележио си ту зиму...).
\end{abstract}

Ключевые слова: музыкальный сленг, словообразование, суффиксация, заимствованные слова, сербский язык, русский язык, польский язык. 